\title{
A NATIONAL LIBRARY FOR THE BAHAMAS
}

by Paul G. Boultbee

\begin{abstract}
Primarily, a library is a storehouse of knowledge containing a permanent and, in many cases, a comprehensive store of information. However, a collection of books, periodicals, maps and the like is hardly a library if the information is not accessible. Ultimately a library is a collection of information made useful.
\end{abstract}

The foremost use of this information is in the area of education. A library, whether it be public, academic or special, should not only complement and supplement formal education but should also be made available for selfeducation. Early founders of libraries realized the need for education beyond formal schooling and recognized that a library was the one social institution that could best fill this need. This led, in the eighteenth century, and more profoundly the nineteenth century, to the establishment of subscription libraries and Mechanics' Institutes as well as various learned societies. The Mechanics' Institutes were developed around 1820 in the United Kingdom for the working men, the mechanics and artisans, who wished to enjoy the benefits of education particularly in relation to their trades and occupations. The idea of Mechanics' Institutes spread throughout the world and in time these institutions evolved into public libraries.

Library service that we now enjoy in The Bahamas, especially in Nassau, owes its origins to the developments mentioned above. The Nassau Public Library on Shirley Street was created through the union of the Bahamas Society for the Diffusion of Kinowledge and an unnamed reading society and established in January 1837. Originally situated in the Eastern Public Building, the Library moved to its present location, the Old Prison, in 1873. Several libraries in the Family Islands were established in the mid1850s while further libraries on New Providence were not established until well into the twentieth century. Presently there are five public libraries in Nassau and thirty-five public libraries in the Family Islands. Freeport is served by the John Harvard Library, an independent institution.

Public libraries in Nassau suffer a great many problems all fairly much due to a lack of funds, a lack of space and a lack of trained personnel. Public libraries in the Family Islands, those that are still functioning, do so with great difficulty.

It is clear that if The Bahamas wishes to enjoy a good, useful library service which, because of the large youth population and the country's status as a developing nation, is necessary, steps must be taken on a national level to ensure that this library service becomes a reality. 
The first responsibility of a national library service is one of coordination leading ultimately to co-operation. For the most part Bahamian public libraries function separately and independently of one another. This does not allow for proper utilization of funds and manpower both of which are at a premium. The Bahamas, because of its size and its resources, must be most concerned with regard to duplication and waste in library service.

To achieve a proper national library service one must begin with sound legislation which should be designed to promote co-ordination amongst all libraries and provide for a steady development of services throughout the country. Since 1970 three reports have been written on library service in The Bahamas and all three have stressed the need for proper legislation before any steps are taken to establish a national library system. Without such legislation and guidelines a national system would surely flounder and any newly established libraries would meet the fate of all present libraries which themselves exist under haphazard legislation.

Once a library act for The Bahamas has been established then a great deal of work can be done to improve library service on a national scale. The major duties of a national library in TheBahamas should be two-fold. On the one hand the library should function as a centre of co-ordination for all libraries in the nation be they public, school, special or academic. On the other hand the national library must provide services peculiar to a national library as this term is understood in the field of librarianship.

There are basically four types of libraries, other than national libraries, to be found in any society. They are, as mentioned above, public, school, special and academic. Each of these types serves a particular purpose and clientele. The public library must cater to individuals from all walks of life with a variety of interests and educational backgrounds. School and academic libraries are similar in that their clientele is, for the most part, limited by age and educational grade level. One must remember that these libraries should provide materials not only for the students of the institution in which they exist but also for the teachers and lecturers within those institutions. Special libraries are relatively new to The Bahamas and by the very nature of their name provide specialized services for a special clientele. Such libraries may exist in government ministries and departments, banks, industries and so on.

It is not an easy task for a national library to co-ordinate all the services and resources of these various types of libraries but it is a task that must be done. Geographically, The Bahamas presents a problem for the adequate provision of library services. Our scattered islands can become too easily isolated and without a co-ordinating centre library service will suffer. This can be seen in libraries that have already been established in the Family Islands. Through neglect they have, in many instances, ceased to exist. A national library service must not allow this to happen. But rather efforts must be made through co-ordinated acquisitions, technical services, staffing and training, and interlibrary loan to maintain and improve library service throughout the nation. 
This co-ordination will not only provide adequate library services but will also limit duplication and waste both of which heavily tax many library programmes. For instance, the national library system can co-ordinate services between one public library and several surrounding school libraries allowing the school libraries to concentrate on particular types of materials while the public library can complement and supplement those materials with major information resources of its own. Such co-ordination would be most useful in the Family Islands where one or two public libraries per island working in concert with the national library can not only provide materials for the public they serve but also assist the school libraries in meeting their particular needs. Similarly, the national library must work closely with special and academic libraries in devising an integral network of library services and resources.

One cannot place too much emphasis on the co-ordinating activities of the national library. These activities will be absolutely necessary in establishing and maintaining library services for the nation.

A national library must also offer particular services which are the peculiar responsibilities of national libraries throughout the world. Firstly, the national library is a repository of all materials, print and non-print, private and governmental, that are published and produced in the country. In order to establish and maintain this collection a depository law is necessary to ensure that copies of all materials are placed in the national library collection. This collection, in our case, a collection of Bahamiana, would be strengthened by acquiring all materials published about the country irrespective of place of publication. To make the collection even more effective works of a regional nature should also be added.

Secondly, the national library must house a collection of books, periodicals, microforms and audio-visual materials which would act as a basic foundation collection for the nation. Writing in 1973, Enid Baa and Mary Heneghan advised that this basic collection should initially consist of 440,000 volumes based on two volumes per capita using the 1973 population estimate of 220,000 with an increase of 100,000 volumes over twenty years. They also recommended that of this initial collection, 220,000 volumes should be for children and young adults. Obviously, these figures would be higher due to population increases since their recommendations were made.

Thirdly, the national library must make its collections useful and accessible. All national libraries produce bibliographies, check-lists and guides and a national library for The Bahamas should be no different. It is the responsibility of this library to produce a national bibliography, both current and retrospective, and to maintain a national union catalogue, a listing of all materials held in all libraries of the nation. This leads quite naturally to interlibrary loan on a national and international scale. By possessing a union catalogue the national library can facilitate loans between libraries within the country and provide materials and information to libraries outside the country. In the same vein the national library must provide extensive reference services to individuals, public and private institutions, and other libraries. 
Fourthly, the national library must constantly work with all libraries in the nation by providing consultants to assist with library development, by providing technical services for the processing of library materials, and by providing mobile library services to isolated or sparsely populated areas of the country.

Fifthly, the national library must provide training for staff members through courses locally and abroad and through a series of workshops or refresher sessions. This also means that the national library will be responsible for setting and maintaining professional standards for librarianship throughout the country.

Finally, the national library must continually provide publicity for all libraries in 'The Bahamas and mount, not unlike the Archives' exhibits, lectures, and special programmes for the community.

The establishment of a national library system itself must be undertaken in three steps. I have already indicated that proper library legislation is necessary before any steps are taken to organize a national library system. This is the first step.

Secondly, temporary central library headquarters must be established in Nassau. This is necessary at the outset for administration purposes and general planning.

The third step is to provide a permanent library building which would house the administration facilities and provide the physical space to house a central book collection and reference resources for the nation as well as special services and collections, and generous seating accommodation for research purposes. This library building must be planned carefully in order to realize the best possible benefits for the funds expended. It must be situated so as to be convenient and beneficial to the maximum number of patrons. Its exterior design must be such that it invites immediate entrance and its interior design must be attractive and functional. Ideally, it should be designed to serve its purpose adequately for 20 years so that a good economic return may be made on the initial investment.

I should like to make one final point and that is, a national library is more than just a building, it is a concept. It is a co-operative network of services and information involving the national community and all libraries of the nation.

The responsibilities of a national library for The Bahamas are great indeed. One might say that we are starting from scratch in attempting to provide a truly national library service. However, it is a service that is needed. A developing nation such as ours depends upon knowledge and information. It is difficult to convince many people of the importance of libraries for the results are not immediately tangible but we cannot be concerned with the short term. It is the future of this nation that must be foremost in our minds and the future of any nation depends upon its citizens. If they are illprepared to accept the challenges that face them the nation cannot grow. A national library service and all that it has to offer can go a very long way in helping the citizens of The Bahamas to meet those challenges. 